NBER WORKING PAPER SERIES

\title{
THE SOURCES OF THE PRODUCTIVITY REBOUND AND THE MANUFACTURING EMPLOYMENT PUZZLE
}

\author{
William Nordhaus \\ Working Paper 11354 \\ http://www.nber.org/papers/w11354 \\ NATIONAL BUREAU OF ECONOMIC RESEARCH \\ 1050 Massachusetts Avenue \\ Cambridge, MA 02138 \\ May 2005
}

The views expressed herein are those of the author(s) and do not necessarily reflect the views of the National Bureau of Economic Research.

(O2005 by William Nordhaus. All rights reserved. Short sections of text, not to exceed two paragraphs, may be quoted without explicit permission provided that full credit, including $\odot$ notice, is given to the source. 
The Sources of the Productivity Rebound and the Manufacturing Employment Puzzle William Nordhaus

NBER Working Paper No. 11354

May 2005

JEL No. O4, E1

\begin{abstract}
Productivity has rebounded in the last decade while manufacturing employment has declined sharply. The present study uses data on industrial output and employment to examine the sources of these trends. It finds that the productivity rebound since 1995 has been widespread, with approximately two-fifths of the productivity rebound occurring in New Economy industries. Moreover, after suffering a slowdown in the 1970s, productivity growth since 1995 has been at the rapid pace of the earlier 1948-73 period. Finally, the study investigates the relationship between employment and productivity growth. If finds that the relevant elasticities indicate that more rapid productivity growth leads to increased rather than decreased employment in manufacturing. The results here suggest that productivity is not to be feared - at least not in manufacturing, where the largest recent employment declines have occurred. This shows up most sharply for the most recent period, since 1998. Overall, higher productivity has led to lower prices, expanding demand, and to higher employment, but the partial effects of rapid domestic productivity growth have been more than offset by more rapid productivity growth and price declines from foreign competitors.

William Nordhaus

Yale University, Department of Economics

28 Hillhouse Avenue

Box 208264

New Haven, CT 06520-8264

and NBER

william.nordhaus@yale.edu
\end{abstract}


After two decades of dismal performance in the 1970s and 1980s, productivity growth rebounded in the late 1990s. It continued to perform at extraordinarily high rates in the early 2000s through a stock market bust, a recession, an investment decline, rising fiscal deficits, skyrocketing oil prices, and interminable small wars.

The sources of the productivity rebound have been widely studied, and most analysts attribute the turnaround to the New Economy - computers, semiconductors, software, and telecommunications. What has been the most recent experience? Has that fantastic sector continued to be the source of rapid growth in the last four years? What has been the impact of rising productivity growth on employment? Those are the issue addressed by the present paper.

\section{Background and Data}

I first lay out the analytical measures employed in this study along with the data used to decompose productivity growth by sector.

\section{A. Analytical Measures of Productivity Growth}

I begin with a summary of alternative approaches to measuring productivity growth. The customary approach to measuring productivity growth is (a) the difference of growth rates approach. This defines productivity growth as the difference between the growth rate of output and the growth rate of inputs. In an earlier paper, I showed that this is not an appropriate welfare-theoretic measure of productivity growth. ${ }^{1}$ I proposed two alternative

\footnotetext{
1 William D. Nordhaus, "Productivity Growth and the New Economy," Brookings Papers on Economic Activity, 2001: 2, pp. 211-265.
} 
measures: (b) a welfare-theoretic measure, which is defined as the currentweighted average of productivity growth where the weights are the shares of nominal output and (c) a fixed-weight measure, which has the same basic construction as the welfare-theoretic measure except that it uses nominal output weights of a given period.

We can summarize these points in terms of a decomposition equation for the growth in productivity:

(1) $a_{t}^{T}=\sum_{i=1}^{n} a_{i, t} \sigma_{i, 0}+\sum_{i=1}^{n} a_{i, t}\left(\sigma_{i, t}-\sigma_{i, 0}\right)+\sum_{i=1}^{n} s_{i, t}\left(\sigma_{i, t}-\mu_{i, t}\right)$

where $a_{t}{ }^{T}$ is the aggregate or total growth of output per unit input, $a_{i, t}$ is the growth of output per unit input in industry $i, \sigma_{i, t}$ is the share of industry output in total nominal output in period $\mathrm{t}, \mu_{i, t}$ is the share of inputs used in industry $i$ of total inputs, and year $t=0$ is a base year for calculations. The term $\left(\sigma_{i, t}-\sigma_{i, 0}\right)$ is the difference between the current share and the base-period share of nominal output of industry $i$, while $\left(\sigma_{i, t}-\mu_{i, t}\right)$ is the difference between the share of nominal output and of inputs in industry i. The first term on the right-hand-side of equation (1) is the fixed-weight measure of productivity growth, $a_{t}^{F}=\sum_{i=1}^{n} a_{i, t} \sigma_{i, 0}$; while the sum of the first two terms of equation (1) is the welfare-theoretic measure of productivity, which is defined as $a_{t}{ }^{W}=\sum_{i=1}^{n} a_{i, t} \sigma_{i, t}$. 


\section{B. Industrial Output Data}

The present study relies on data on the aggregate and by detailed and broad industry group. The variables are primarily real and nominal value added, and labor inputs measured as hours worked and persons engaged. The published data available to decompose productivity by industry has major comparability problems. There are four different data sets for industrial output available from the Bureau of Economic Analysis:

A. Industrial output (real value added, nominal value added, and prices) by 1972 SIC industrial classification using fixed-price weights, available for the 1948-87 period.

B. Industrial output by 1972 SIC code for the period 1977-1987 using chainweighted indexes.

C. Industrial output by 1987 SIC code for the period 1987-2001 using chainweighted indexes.

D. An entirely different data set using chain-weighted indexes available starting in 1998 using the NAICS industrial classification. These data include indexes of real value added, prices, along with hours and persons engaged in employment.

Together with Alexandra Miltner, the present author developed an integrated data set for all industries for 1948-2001 that integrates the first three data sets. This data set was used to analyze the productivity slowdown in a companion paper. ${ }^{2}$

Unfortunately, there is virtually no overlap among sectors in the old and

\footnotetext{
2 William Nordhaus, with Alexandra Miltner, "A Retrospective on the Postwar Productivity Slowdown," NBER Working Paper No. W10950, December 2004.
} 
new classification systems. Moreover, while BEA has shifted from the earlier SIC industrial classification to the NAICS system, the industrial data using the earlier industrial classification have been discontinued, the NAICS data go back only to 1998, and it is virtually impossible for private scholars to map the SIC into the NAICS system.

In order to examine the sources of the labor-productivity rebound, the present study uses the methods described in the last section on the NordhausMiltner data set as well as the new NAICS data set. Even though the data sets use different industrial classifications, under ideal conditions they will aggregate up to the same aggregate estimate of total productivity growth. ${ }^{3}$

A brief word on the use of labor productivity rather than total factor productivity. The introduction of capital inputs raises several issues, particularly for short periods of time. My earlier productivity paper reviewed many of the issues, and these are summarized in the accompanying footnote. ${ }^{4}$

\footnotetext{
3 The "ideal conditions" require that price and output indexes are consistent and that there be no Fisher aggregation bias. In this study, we rely instead on Törnqvist aggregation, which has no aggregation bias.
}

4 Among the problems which arise, particularly for the 1998-2003 period, are the following: (1) Multifactor productivity depends upon estimating rather than measuring the inputs of capital services. Estimates of capital services depend upon several critical and questionable assumptions (including such things as the existence of perfect rental markets for capital, no difference between ex ante and ex post substitutability, no break-in, adjustment, or learning costs, perfect competition, and factor rewards proportional to marginal products). These assumptions are likely to be stretched particularly then in periods, such as the 1998-2003 period, when new technologies with very high rates of depreciation dominate the data on the growth of capital services. (2) Measures of capital services generally use a cost of capital formula based on interest rates and therefore do not reflect the extraordinary equity valuations in the late 1990s; the effect of this is to overestimate the user cost and implicit marginal cost of capital, particularly in high-tech industries. (3) Multifactor production functions generally include only the return to fixed capital as a non-labor market inputs and exclude the return to other assets such as land, inventories, intangible assets such as patents and trademarks, brand value and marketing, and subsoil assets such as oil and gas reserves. (4) Inclusion of capital inputs gives productivity a pro-cyclical character. For a further discussion, see William D. Nordhaus, 


\section{Extent and Sources of the Productivity Rebound}

\section{A. General Trends}

It will be useful to begin with a description of the general trends. Figure 1 shows data on productivity growth for the total economy for the period 19482004. For this calculation, I have used BEA's estimate of hours worked by fulltime and part-time employees as the input. There are three different output concepts, two built up from the industry accounts and one using aggregate real GDP from the NIPA accounts. I have taken the three-year moving average of the logarithmic growth rate of output per hour to smooth the data. Table 1 shows the same data grouped by different periods.

Figure 2 shows the same results using a more restricted output concept, "Business output," which is a BEA-BLS concept used for BLS productivity measures. Business excludes government, non-farm housing, as well as not-for profit sectors. It is not possible to map the expenditure BEA-BLS concept of business output directly into industry measures, but I have made as close an approximation as is possible with existing data sources. Table 2 shows the same data grouped by periods.

Finally, it will be useful to provide estimates of the extent of the rebound of productivity since the mid-1990s. Figure 3 shows both NIPA and industry data for the two concepts grouped into four subperiods. ${ }^{5}$ For both the total

\footnotetext{
"Productivity Growth and the New Economy," Brookings Papers on Economic Activity, 2001: 2, pp. 211-265.

${ }^{5}$ For Figure 3, I have created a merged business productivity series that splices the SIC and NAICS data.
} 
economy and the business sector, productivity growth has returned to their trends during the 1948-73 period.

Three points about these results can be seen from the tables and figures. First, the different sources are very consistent for GDP, but somewhat less consistent for business output. The difficulties in estimating business productivity are likely to reside in attempting to match the BEA-BLS (expenditure) concept of business output with income-side data from the industry accounts. Business output under the NAICS concept is substantially lower that for the BLS concept: 2.82 percent per year in the former as compared to 3.37 percent per year for the latter during the 1998-2003 period. It should be emphasized, however, that the productivity data are not necessarily inaccurate, because the output and hours data are matched by industry.

Second, business output productivity is between one-quarter and onehalf percentage points higher than GDP productivity depending upon the time period and concept.

Third, as can be best seen in the graphs, for both total GDP and for business output, productivity growth since 1995 has rebounded very sharply. For the last two years, productivity has returned to the peak years in the 194873 period. Moreover, while the detailed industry classification system changed greatly from the SIC to the NAICS system, the two systems appear to aggregate to similar numbers for total GDP. 


\section{B. Rebound by Industry}

1. Results for broad industry groups, 1998-2003

We next examine the sources of the rebound by industry. For broad industry groups (non-durable manufacturing, construction, information, etc.), BEA publishes both hours worked as well as real and nominal value added and prices by industry. In addition, we have separated out Computers and electronic products from Durable manufacturing because of the importance of computers in the overall productivity numbers. ${ }^{6}$ Using these data, we can use equation (1) above to determine the sources of the productivity rebound over this period.

Table 3 shows productivity growth by major industry group, while Table 4 shows the contribution of each major industry to the overall productivity growth. For this period, Computers and electronic products continued to show very rapid productivity growth, averaging a torrid 26 percent per year. Information industries and Retail trade also showed very rapid growth.

In estimating the contribution of each of the industries to the total shown in Table 4, we use the fixed-weight productivity growth $\left(a_{t}^{F}\right)$, using average shares for the period 1998-2003. Over this period, weighted productivity growth for the entire economy was 2.49 percent per year, which was, not

\footnotetext{
${ }^{6}$ Computers were separated out by constructing a Törnqvist index of output growth of durable manufacturing output and computer output growth for 1998-2003. It was assumed that hours worked per person engaged in the computer subsector is equal to that for all of durable manufacturing. While the Törnqvist index gives slightly different results from Fisher aggregation, the difference is extremely small.
} 
surprisingly, entirely driven by private industries. However, the source of the rapid growth is a surprise. The largest source was Finance, insurance, real estate, and related industries, contributing 0.72 percentage points or 29 percent of the total weighted productivity growth. Computers and electronic products contributed 0.43 percentage points, or 17 percent of the total. Other important major industries were Retail trade, Information, and Professional services. Other services, Government, and Construction continued to show essentially no productivity growth and contributed nothing, at least as measured in the national accounts.

\section{Results for detailed industries, 1998-2003}

We next drill a little deeper to determine which detailed industry showed the major contribution to the productivity rebound. The data for detailed industries cover only persons engaged rather than hours worked. Productivity per person rises more slowly than productivity per hour, but the major trends are likely to be accurately captured in these estimates. ${ }^{7}$

Table A-1 in the appendix shows the growth in productivity per person engaged for all industries, while Table 5 shows the results for the top 15 industries. There is no major surprise in the rapid growth in Computers. However, the performance of Securities, commodity, and investments; Information and data processing services; and Apparel and leather and allied products may be more of a surprise. We return below to further tests of these data.

\footnotetext{
${ }^{7}$ An additional complication is that hours worked exclude the hours of self-employed workers. Table A-3 in the Appendix shows a calculation of the potential bias from excluding self-employed hours, using BEA data. The bias in the overall productivity numbers are in the order of plus or minus 0.05 percentage point per year. Agricultural productivity is likely to have a downward bias of abound 1 percentage point per year. There may also be a small upward bias in the estimated hours worked in Information, Professional services, and Other services, but the bias is unlikely to be larger than 0.2 percentage points per year in any non-agricultural sector.
} 
The next question is how much each industry contributed to the overall productivity growth in the 1998-2003 period. Table A-2 in the appendix shows the contribution of individual industries to the aggregate fixed-weighted productivity growth in productivity per person engaged, while Table 6 shows the results for the top 15 industries. Of the 208 basis point per year average productivity growth, 40 basis points came from Computers and electronic products and 46 basis points came from Retail and Wholesale Trade.

\section{The New Economy}

We next examine the extent to which the New Economy sectors were responsible for the rapid productivity growth in the 1998-2003 period using the output per person measure. The measure of contribution here includes only the direct measure from production of new-economy goods; it excludes any contribution of new-economy capital services in using industries. Table 7 shows the major new economy sectors (which is an overly generous bundle but is at the most disaggregated level available). ${ }^{8}$ These sectors enjoyed a rapid rate of productivity growth: 10.1 percent per year over the 1998-2003 period. All six new economy sectors were responsible for 76 basis points of the 208 basis point growth rate in employment productivity, or 36 percent of the total. This estimate compares with an estimate in my earlier study, using the same methodology but different industrial definitions, in which the New Economy contributed 64 basis points of the 224 basis point growth in hourly productivity, representing 29 percent of productivity growth in the 1995-2000

\footnotetext{
8 Inclusion of extraneous industries will inflate the nominal share in GDP of New Economy industries but will inflate their contribution to total productivity only slightly.
} 
period. ${ }^{9}$ The difference is not large but probably lies mainly in the aggregate productivity rather than the impact of the New Economy industries because overall employment productivity grew at 40 basis points more slowly over the 1998-2003 period than hours productivity.

\section{Test of the Coherence of the Data}

The industrial productivity data are a black box to outside researchers, and it is not easy to validate them with alternative data. One way of testing their plausibility is to examine the productivity identity to see whether the productivity growth is associated with price changes, employment changes, compensation, or share changes. Begin with the definition of labor's share of value added:

$$
Z_{i, t}=W_{i, t} E_{i, t} / X_{i, t} P_{i, t}
$$

where $\mathrm{Z}$ is the share of labor in value added, $\mathrm{W}$ is real compensation per person engaged, $\mathrm{E}$ is persons engaged, $\mathrm{X}$ is real output, and $\mathrm{P}$ is the valueadded price index relative to the GDP price index. Taking logarithmic changes over the 1998-2003 period and designating the lower case letters as the annual average logarithmic change yields productivity growth per person $\left(\mathrm{a}_{\mathrm{i}, \mathrm{t}}\right)$ as:

(2) $a_{i, t}=x_{i, t}-e_{i, t}=w_{i, t}-p_{i, t}-z_{i, t}$

We would normally expect that the shares of labor would be relatively stable and that wage-rate growth would not differ greatly by industry, in which case the productivity growth would be reflected in a price decline. A

\footnotetext{
9 William D. Nordhaus, "Productivity Growth and the New Economy," Brookings Papers on Economic Activity, 2001: 2, pp. 211-265.
} 
cross-sectional regression of price change on productivity change indicates that the coefficient is -1.002 with a standard error of the coefficient of 0.086 . Table 8 shows the decomposition for the industries with the five highest and five lowest productivity growth over the 1998-2003 period. Computers and Securities show price changes that are parallel to the productivity increase. Given that the price decline in computers is well established, we can take these results as plausible.

The next industry on the list is "Securities, commodity contracts, related." The price decline here is extremely rapid: the relative price index for value added in this industry (NAICS 523) declined 15 percent per year over the 19982003 period. Discussions with BEA staff indicate that output for this industry through 2000 was based on a quantity index measuring public orders for equities traded on registered exchanges and over-the-counter markets; after 2000 , the quantity index was created by deflating nominal output with a new producer price index for financial services.

Are the underlying price indexes for Securities plausible? Have they been extrapolated appropriately to the entire industry? Some skepticism seems warranted. BEA has only recently attempted to measure real output in the financial-service industries. The price and quantity indexes just discussed do not seem representative of the entire industry, and the rapid measured productivity growth may be largely an artifact of rapidly falling commission rates during this period. However, the calculations are largely a mystery to this outsider. Hence, a question mark remains over this result; given that the Securities industry contributed 26 basis points to the overall productivity growth during the rebound period, validation of this number would seem to be a high priority. 
The rest of the top and bottom industries in Table 8 are puzzling because prices do not generally move with productivity. Many are poorly measured, particularly in the bottom five. For example, Oil and Petroleum industry value added real output has proved to be highly unreliable in the industry data. Overall, the data are reasonably coherent in most well-measured industries.

\section{Is Productivity Growth Good for Employment?}

One of the major debates in recent years has been the role of productivity in employment. Some have argued that the rapid growth of productivity, particularly in manufacturing, has hurt workers in those industries by leading producers to shed jobs. Critics of this point of view generally argue that, while this might be true for a particular firm or industry, or might hold in the short run, in the longer run the level of jobs and unemployment will be determined by macroeconomic policies rather than by productivity growth.

While technological change is unlikely to have a major impact on aggregate unemployment or employment in the long run, this point most definitely does not apply to individual industries. The employment of workers in the typewriter industry was most definitely affected by technological trends there and in computers. At the microeconomic level, the impact of productivity growth on employment is ambiguous and depends upon the bias of technological change, on prices of competing goods and services, and on the price-elasticity of demand.

To explore this relationship, I sketch a simplified model. Assume demand is given by: 


$$
X_{i, t}=B_{i}\left(P_{i, t} / P_{i, t}{ }^{C}\right)^{-\lambda_{i}} Y_{t}^{\mu_{i}}
$$

where $X_{i, t}$ is output, $P_{i, t}$ is own price, $P_{i, t}{ }^{C}$ is the price of competing goods, $Y_{t}$ is real income, and $-\lambda_{i}$ and $\mu_{i}$ are price and income elasticities. Further, assume that production is given by

$$
X_{i, t}=A_{i, t} K_{i, t}^{\alpha_{i}} L_{i, t}^{1-\alpha_{i}}
$$

where $A_{i, t}$ is total factor productivity, $K_{i, t}$ is capital inputs, $L_{i, t}$ is labor inputs, and $\alpha_{i}$ is the Cobb-Douglas elasticity. For this discussion, we further assume either that production is Cobb-Douglas or that technological change is Hicksneutral.

The basic argument is straightforward. The average and marginal costs of production are $A_{i, t}{ }^{-1} R_{i, t}^{-\alpha_{i}} W_{i, t}^{-\left(1-\alpha_{i}\right)}$ where $W_{i, t}$ is the wage rate, $R_{i, t}$ is the cost of capital, and we have normalized for any inessential constants. If each firm behaves competitively, profit-maximizing price is $P_{i, t}=A_{i, t}{ }^{-1} R_{i, t}{ }^{-\alpha_{i}} W_{i, t}{ }^{-\left(1-\alpha_{i}\right)}$. This implies that price declines proportionally with productivity. Let $\Delta a_{i, t}$ be the logarithmic increase in $A_{i, t}$; then, with other variables unchanged, the increase in output is $\lambda_{i} \Delta a_{i, t}$, and inputs increase by $\left(\lambda_{i}-1\right) \Delta a_{i, t}$. With Hicks-neutral technological change, both employment and capital inputs increase by $\left(\lambda_{i}-1\right) \Delta a_{i, t} \cdot{ }^{10}$

10 The story would be different if technological change is not neutral and production is not CobbDouglas, but in either of these cases employment (or more generally labor inputs) will be positively related to technological change if the demand for output is price-elastic $(\lambda>1)$. If the market structure is non-competitive or if there are non-constant-returns to scale, then foreign prices and output effects will enter as well. 
Note that the trend levels of production and employment will depend not only on domestic productivity but also on competing prices, incomes, and elasticities. Since $\Delta p_{i, t}=-\Delta a_{i, t}$, the growth in production and employment will be given by:

$$
\begin{aligned}
& \Delta x_{i, t}=b_{i}+\lambda_{i} \Delta a_{i, t}+\lambda_{i} \Delta p_{i, t}{ }^{C}+\mu_{i} \Delta y_{t} \\
& \Delta e_{i, t}=b_{i}+\left(\lambda_{i}-1\right) \Delta a_{i, t}+\lambda_{i} \Delta p_{i, t}{ }^{C}+\mu_{i} \Delta y_{t}
\end{aligned}
$$

where again the lower case letters in (5) and (6) are logarithms of the upper case letters in (3) and (4), and $\Delta$ represents time differences.

The partial relationship of changes in employment with changes in productivity is seen to be $\partial \Delta e_{i, t} / \partial \Delta a_{i, t}=\lambda_{i}-1$, as described above. However, the trend or total effect would need to include income effects and the prices of competing goods. In industries like agriculture, with rapid technological change and inelastic price and income effects, both employment and the industry share of nominal output are likely to decline over time. In manufacturing, with price-elastic demand, the positive effect of technological change may be offset for employment if the prices of competing goods are falling rapidly. The paradoxical case, with rapid productivity growth and falling employment, appears to hold for the United States, while the opposite case, with manufacturing employment growing because domestic costs and prices are falling rapidly, would hold most notably for China.

There are many potential empirical approaches to determining the historical effect of productivity growth on employment, but for this purpose, 
we will use the BEA industry data discussed above. The estimated relationship between employment growth $\left(\Delta e_{i, t}\right)$ and productivity growth $\left(\Delta a_{i, t}=\Delta x_{i, t}-\Delta e_{i, t}\right)$ is:

$$
\Delta e_{i, t}=\beta_{i}+\gamma_{t} \Delta a_{i, t}+\varepsilon_{i, t}
$$

where $\beta_{i}$ and $\gamma_{t}$ are parameters, and $\varepsilon_{i, t}$ is a residual. The residual includes not only random effects and measurement errors but also the impact of omitted variables, such as income effects and the prices of competing goods (such as imports or competing exports). An important assumption is that movements in these omitted variables are independent of short-run movements in productivity. The main concern about this specification is that errors in measuring output will lead to biased estimates of $\gamma_{t}$; indeed, they are likely to lead to a downward bias in the estimates of $\gamma_{l}$.

Table 9 shows estimates for eight different specifications. These differ first by time period (one being 1955-2001 for the earlier BEA data set and the other being 1998-2003 for the new BEA data set); a second alternative is with current or current and lagged productivity growth; and a third is with least squares or two-stage least squares, with instruments being the current and lagged rate of change of prices as an instrument for productivity growth (because prices and productivity are independently measured for most manufacturing industries). In each case, the industries are the 21 or 19 manufacturing industries in the old and new data set, respectively.

The results for manufacturing are relatively sharp in both data sets. In the old data set, the impact of productivity growth on employment is uniformly 
positive, and significantly so in two of the four estimates. The coefficients (partial elasticities) are between 0.05 and 0.10 , indicating that a 10 percent increase in productivity growth above trend would lead to a $1 / 2$ to 1 percent increase in employment.

For the new and shorter data set, all current coefficients are significant, and three are significant at the 1 percent level. In addition, there is a suggestion of a significant lagged effect. In the new data set, the TSLS estimates provide higher coefficients, indicating that there may be a downward bias in the OLS results due to measurement error in output. Overall, the estimates in the more recent data indicate that the elasticity of employment with respect to productivity is at least $1 / 4$ and might be as high as $1 / 2$. Finally, the coefficients are much larger in the new data set, which suggests that demand is more elastic in the later period because the U.S. economy is more open to international trade.

The empirical results presented here sharply reject the view that higher growth in manufacturing productivity leads to a decline in employment. How are these findings consistent with the rapid growth in manufacturing productivity and the decline in manufacturing employment? The answer lies in the determinants of trend output and employment shown in equations (5) and (6). It is likely that productivity and costs in other countries, such as China, have been declining even more rapidly than in the United States. This is obvious in some industries, such as consumer electronics or apparel, where China simply did not compete two decades ago and Chinese prices were from an economic point of view essentially infinite. 
The tentative conclusion here is suggestive of the views of the labor leader John L. Lewis of the United Mine Workers. His philosophy was that productivity advances in that industry should lead to increased production and employment and that the union should not resist modern techniques. Given the elasticities, Lewis may have been wrong about coal, but he was probably right about manufacturing.

\section{Conclusion}

The late 1990s and early 2000s have seen a rapid growth in productivity in the American economy. A close examination of the rebound finds that rapid growth is centered in the New Economy but is much more widespread than simply computers and semiconductors.

This study also asks whether workers should be fearful of rapid productivity growth in light of the decline in non-farm employment. The results here suggest that productivity is not to be feared - at least not in manufacturing, where the largest employment declines have occurred. On the whole, higher productivity has led to lower prices, expanding demand, and quickly to higher employment, but the partial effects of rapid domestic productivity growth have been more than offset by more rapid productivity growth and price declines from foreign competitors. 


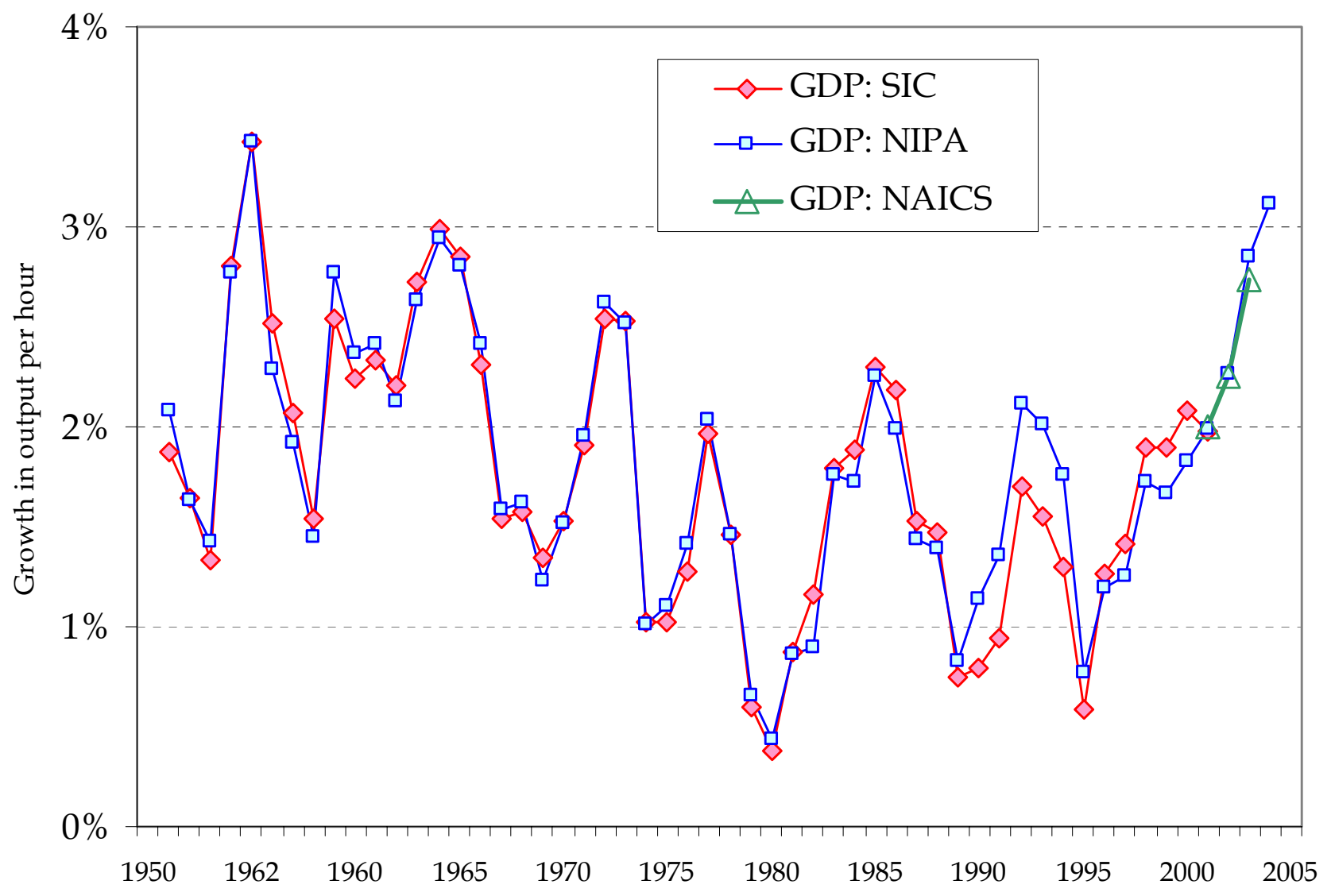

\section{Figure 1. Comparison of growth in GDP per hour, alternative output sources}

This figure shows productivity growth according to three measures:

"GDP: SIC" = GDP per hour constructed by author by aggregating from earlier industry data (i.e., from 1972/1987 SIC industrial classification)

"GDP: NAICS" = GDP per hour aggregated by author from latest industry data (i.e., from NAICS industrial classification)

"GDP: NIPA" = output per hour from real GDP in the NIPA accounts 


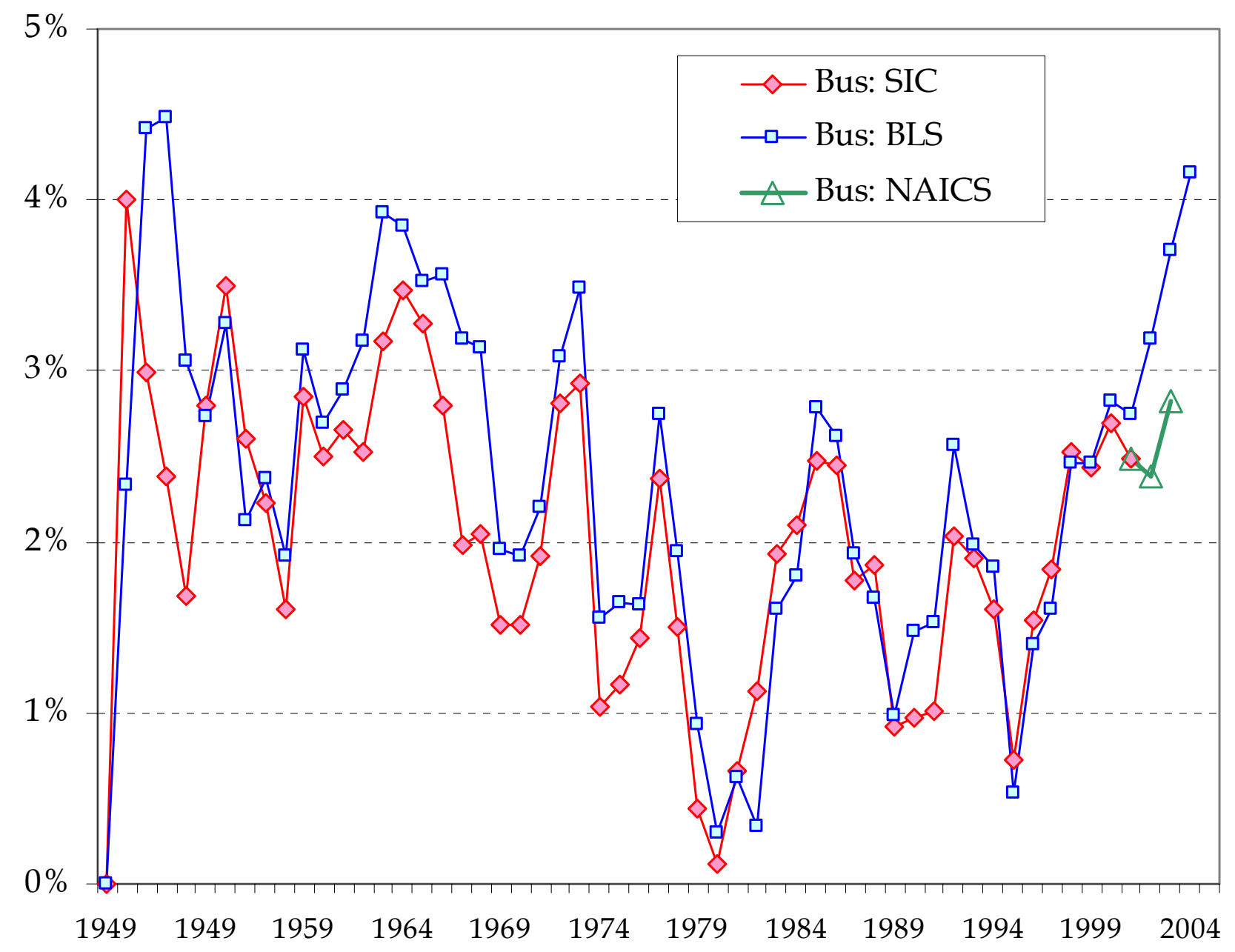

Figure 2. Comparison of growth in business output per hour, alternative output sources

This figure shows productivity growth according to three measures:

"Bus: SIC" = Output per hour in business sector constructed by author by aggregating from earlier industry data (i.e., from 1972/1987 SIC industrial classification)

"Bus: NAICS" = GDP per hour in business sector aggregated by author from latest industry data (i.e., from NAICS industrial classification)

"Bus: NIPA" = output per hour for business output from BLS 


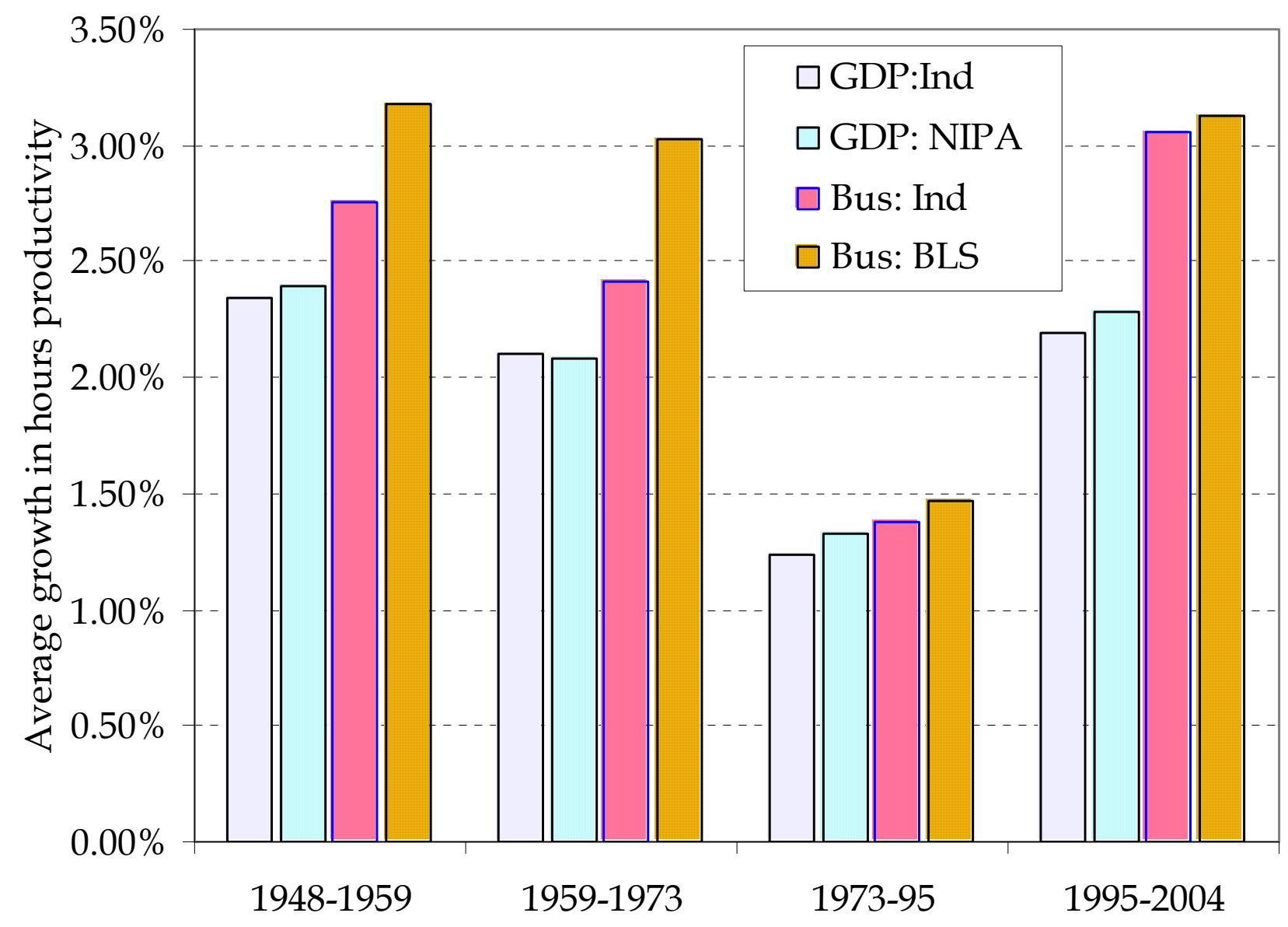

Figure 3. Productivity Growth in Four Epochs, Different Concepts

For industry definitions, see Figures 1 and 2 


\begin{tabular}{|l|r|r|r|r|r|}
\hline & \multicolumn{5}{|l|}{$\begin{array}{l}\text { Growth in output per hour, GDP } \\
\text { Average annual logarithmic growth, percent per year }\end{array}$} \\
\cline { 2 - 7 } & $1949-1959$ & $1959-1973$ & $1973-95$ & $1995-2001$ & $1998-2003$ \\
\hline $\begin{array}{c}\text { Industry accounts } \\
\text { SIC } \\
\text { NAICS } \\
\text { NIPA }\end{array}$ & $2.34 \%$ & $2.10 \%$ & $1.24 \%$ & $1.94 \%$ & \\
& $2.39 \%$ & $2.08 \%$ & $1.32 \%$ & $1.86 \%$ & $2.53 \%$ \\
\hline
\end{tabular}

Table 1. Average productivity growth for GDP by concept and period For industry definitions, see Figure 1

\begin{tabular}{|l|r|r|r|r|r|}
\hline & \multicolumn{5}{|l|}{$\begin{array}{l}\text { Growth in output per hour, business output } \\
\text { Average annual logarithmic growth, percent per year }\end{array}$} \\
\cline { 2 - 6 } & $1949-1959$ & $1959-1973$ & $1973-95$ & $1995-2001$ & $1998-2003$ \\
\hline $\begin{array}{l}\text { Industry accounts } \\
\text { SIC } \\
\text { NAICS }\end{array}$ & $2.76 \%$ & $2.42 \%$ & $1.38 \%$ & $2.50 \%$ & \\
BLS & $3.18 \%$ & $3.03 \%$ & $1.47 \%$ & $2.61 \%$ & $3.37 \%$ \\
\hline
\end{tabular}

Table 2. Average productivity growth for business output by concept and period

For industry definitions, see Figure 2 


\begin{tabular}{|l|ccccc|c|}
\hline & \multicolumn{7}{l}{ Annual logarithmic productivity growth $(\%$ per year) } \\
\cline { 2 - 7 } Sector & 1999 & 2000 & 2001 & 2002 & 2003 & Average \\
\hline Gross domestic product & 2.07 & 2.05 & 1.71 & 2.90 & 3.72 & $\mathbf{2 . 4 9}$ \\
Private industries & 2.24 & 2.38 & 2.28 & 3.39 & 3.92 & $\mathbf{2 . 8 4}$ \\
\hline Agriculture, forestry, related & -0.18 & 9.76 & -12.06 & 5.88 & 9.18 & $\mathbf{2 . 5 2}$ \\
Mining & 11.89 & -3.90 & -8.62 & 7.53 & -6.75 & $\mathbf{0 . 0 3}$ \\
Utilities & 3.45 & 8.82 & -3.04 & 8.94 & 8.43 & $\mathbf{5 . 3 2}$ \\
Construction & -4.11 & -2.96 & 0.58 & -0.67 & -0.02 & $\mathbf{- 1 . 4 4}$ \\
Durable goods other than computers & 0.21 & 4.49 & 0.09 & 7.24 & 3.77 & $\mathbf{3 . 1 6}$ \\
Computer and electronic products & 28.17 & 38.59 & 5.63 & 22.42 & 35.13 & $\mathbf{2 5 . 9 9}$ \\
Nondurable goods & 2.12 & 0.73 & -0.05 & 8.96 & 6.86 & $\mathbf{3 . 7 2}$ \\
Wholesale trade & 5.09 & -3.16 & 8.56 & 4.46 & -1.16 & $\mathbf{2 . 7 6}$ \\
Retail trade & 1.66 & 4.44 & 6.48 & 5.38 & 6.22 & $\mathbf{4 . 8 4}$ \\
Transportation and warehousing & 1.91 & 4.88 & 0.58 & 5.21 & 6.35 & $\mathbf{3 . 7 9}$ \\
Information & 4.84 & 3.11 & 4.46 & 7.45 & 12.14 & $\mathbf{6 . 4 0}$ \\
Finance, insurance, real estate, related & 3.05 & 6.91 & 4.67 & 1.67 & 1.94 & $\mathbf{3 . 6 5}$ \\
Professional and business services & 1.17 & -1.57 & 3.52 & 3.67 & 4.07 & $\mathbf{2 . 1 7}$ \\
Educational services, health care, related & -0.18 & 0.17 & -0.69 & 0.17 & 0.40 & $\mathbf{- 0 . 0 3}$ \\
Arts, entertainment, recreation, related & 0.88 & -0.07 & -0.83 & 0.62 & 1.34 & $\mathbf{0 . 3 9}$ \\
Other services, except government & -2.96 & -1.89 & -2.84 & -3.33 & 1.46 & $\mathbf{- 1 . 9 1}$ \\
Government & 0.52 & 0.32 & -0.58 & -0.35 & 1.14 & $\mathbf{0 . 2 1}$ \\
\hline
\end{tabular}

Table 3. Productivity growth per hour, 1998-2003, by broad industry group 


\begin{tabular}{|l|c|ccccc|c|}
\hline & $\begin{array}{c}\text { Average } \\
\text { share }\end{array}$ & \multicolumn{5}{|c|}{ Contribution to aggregate productivity growth } \\
\cline { 2 - 8 } & $1998-2002$ & 1999 & 2000 & 2001 & 2002 & 2003 & Average \\
\hline Gross domestic product & 100.00 & 2.07 & 2.05 & 1.71 & 2.90 & 3.72 & $\mathbf{2 . 4 9}$ \\
Private industries & 87.50 & 1.96 & 2.08 & 2.00 & 2.97 & 3.43 & $\mathbf{2 . 4 9}$ \\
\hline Finance, insurance, real estate, etc. & 19.74 & 0.60 & 1.36 & 0.92 & 0.33 & 0.38 & $\mathbf{0 . 7 2}$ \\
Computer and electronic products & 1.66 & 0.47 & 0.64 & 0.09 & 0.37 & 0.58 & $\mathbf{0 . 4 3}$ \\
Retail trade & 6.91 & 0.12 & 0.31 & 0.45 & 0.37 & 0.43 & $\mathbf{0 . 3 3}$ \\
Information & 4.62 & 0.22 & 0.14 & 0.21 & 0.34 & 0.56 & $\mathbf{0 . 3 0}$ \\
Professional and business services & 11.53 & 0.13 & -0.18 & 0.41 & 0.42 & 0.47 & $\mathbf{0 . 2 5}$ \\
Durable goods other than computers & 6.78 & 0.01 & 0.30 & 0.01 & 0.49 & 0.26 & $\mathbf{0 . 2 1}$ \\
Wholesale trade & 6.08 & 0.31 & -0.19 & 0.52 & 0.27 & -0.07 & $\mathbf{0 . 1 7}$ \\
Nondurable goods & 5.75 & 0.12 & 0.04 & 0.00 & 0.51 & 0.39 & $\mathbf{0 . 2 1}$ \\
Transportation and warehousing & 3.01 & 0.06 & 0.15 & 0.02 & 0.16 & 0.19 & $\mathbf{0 . 1 1}$ \\
Utilities & 1.97 & 0.07 & 0.17 & -0.06 & 0.18 & 0.17 & $\mathbf{0 . 1 0}$ \\
Arts, entertainment, recreation, etc. & 3.54 & 0.03 & 0.00 & -0.03 & 0.02 & 0.05 & $\mathbf{0 . 0 1}$ \\
Agriculture, forestry, etc. & 1.03 & 0.00 & 0.10 & -0.12 & 0.06 & 0.09 & $\mathbf{0 . 0 3}$ \\
Government & 12.44 & 0.06 & 0.04 & -0.07 & -0.04 & 0.14 & $\mathbf{0 . 0 3}$ \\
Mining & 1.04 & 0.12 & -0.04 & -0.09 & 0.08 & -0.07 & $\mathbf{0 . 0 0}$ \\
Educational services, health care, etc. & 7.09 & -0.01 & 0.01 & -0.05 & 0.01 & 0.03 & $\mathbf{0 . 0 0}$ \\
Other services, except government & 2.40 & -0.07 & -0.05 & -0.07 & -0.08 & 0.04 & $\mathbf{- 0 . 0 5}$ \\
Construction & 4.42 & -0.18 & -0.13 & 0.03 & -0.03 & 0.00 & $\mathbf{- 0 . 0 6}$ \\
\hline
\end{tabular}

Table 4. Contribution of different industries to productivity rebound, 19982003, by broad industry group 


\begin{tabular}{|c|c|c|c|c|c|c|}
\hline \multirow[t]{2}{*}{ Sector } & \multicolumn{6}{|c|}{$\begin{array}{l}\text { Productivity Growth per Person Engaged } \\
\text { [percent per year] }\end{array}$} \\
\hline & 1999 & 2000 & 2001 & 2002 & 2003 & $\begin{array}{r}\text { Average, } \\
1998-2003\end{array}$ \\
\hline Gross domestic product & 2.33 & 1.56 & 0.50 & 2.92 & 3.10 & 2.08 \\
\hline Private industries & 2.58 & 1.76 & 0.91 & 3.40 & 3.28 & 2.39 \\
\hline Computer and electronic products & 28.93 & 37.69 & 2.91 & 22.53 & 35.09 & 25.43 \\
\hline Securities, commodity contracts, and investments & 16.42 & 33.28 & 10.65 & 4.87 & 18.00 & 16.64 \\
\hline Information and data processing services & 12.79 & -2.24 & 13.06 & 16.11 & 13.21 & 10.58 \\
\hline Apparel and leather and allied products & 0.95 & 12.30 & -0.31 & 24.72 & 14.47 & 10.43 \\
\hline Air transportation & 4.50 & 4.72 & -0.29 & 16.06 & 24.93 & 9.99 \\
\hline Publishing industries (includes software) & 16.75 & -5.68 & 5.89 & 4.03 & 11.46 & 6.49 \\
\hline Electrical equipment, appliances, and components & 9.89 & 2.41 & 0.00 & 7.52 & 12.57 & 6.48 \\
\hline Computer systems design and related services & 5.78 & 5.07 & 4.33 & 9.83 & 6.79 & 6.36 \\
\hline Motor vehicles, bodies and trailers, and parts & 0.95 & 3.47 & -5.35 & 18.92 & 11.05 & 5.81 \\
\hline Broadcasting and telecommunications & 8.56 & 2.18 & -4.16 & 6.05 & 12.05 & 4.94 \\
\hline Warehousing and storage & 3.89 & 4.41 & -5.03 & 10.84 & 8.94 & 4.61 \\
\hline Chemical products & 4.68 & -0.13 & -0.06 & 10.19 & 8.37 & 4.61 \\
\hline Textile mills and textile product mills & 4.29 & 9.27 & -9.21 & 8.31 & 10.14 & 4.56 \\
\hline Miscellaneous manufacturing & 3.26 & 9.72 & -2.35 & 5.61 & 5.56 & 4.36 \\
\hline Pipeline transportation & 8.49 & 14.18 & -4.45 & 3.03 & 0.49 & 4.35 \\
\hline
\end{tabular}

Table 5. Growth in Productivity per person engaged:

top 15 of detailed industry groups, 1998-2003 


\begin{tabular}{|c|c|c|c|c|c|c|}
\hline \multirow[t]{2}{*}{ Sector } & \multicolumn{6}{|c|}{$\begin{array}{l}\text { Contribution to Total Productivity Growth } \\
\text { [percent per year] }\end{array}$} \\
\hline & 1999 & 2000 & 2001 & 2002 & 2003 & $\begin{array}{c}\text { Average, } \\
\text { 1998-2003 }\end{array}$ \\
\hline Gross domestic product & 2.33 & 1.56 & 0.50 & 2.92 & 3.10 & 2.08 \\
\hline Private industries & 2.58 & 1.76 & 0.91 & 3.40 & 3.28 & 2.09 \\
\hline Computer and electronic products & 0.53 & 0.69 & 0.05 & 0.29 & 0.45 & 0.40 \\
\hline Retail trade & 0.19 & 0.14 & 0.21 & 0.45 & 0.41 & 0.28 \\
\hline Securities, commodity contracts, and related & 0.25 & 0.54 & 0.18 & 0.08 & 0.27 & 0.26 \\
\hline Wholesale trade & 0.21 & -0.10 & 0.68 & 0.23 & -0.14 & 0.18 \\
\hline Rental and leasing services and related & 0.11 & 0.18 & 0.07 & 0.20 & 0.09 & 0.13 \\
\hline Broadcasting and telecommunications & 0.23 & 0.06 & -0.12 & 0.16 & 0.31 & 0.13 \\
\hline Federal Reserve banks and related & 0.19 & -0.04 & 0.13 & 0.20 & 0.07 & 0.11 \\
\hline Utilities & 0.09 & 0.12 & -0.11 & 0.14 & 0.18 & 0.08 \\
\hline Computer systems design and related & 0.06 & 0.06 & 0.05 & 0.12 & 0.08 & 0.08 \\
\hline Chemical products & 0.08 & 0.00 & 0.00 & 0.16 & 0.14 & 0.07 \\
\hline Publishing industries (includes software) & 0.20 & -0.07 & 0.07 & 0.05 & 0.13 & 0.07 \\
\hline Motor vehicles and related & 0.01 & 0.04 & -0.06 & 0.20 & 0.12 & 0.06 \\
\hline Air transportation & 0.03 & 0.03 & 0.00 & 0.08 & 0.12 & 0.05 \\
\hline Information and data processing services & 0.05 & -0.01 & 0.05 & 0.07 & 0.06 & 0.04 \\
\hline Electrical equipment, appliances, and rel;ated & 0.05 & 0.01 & 0.00 & 0.03 & 0.05 & 0.03 \\
\hline
\end{tabular}

Table 6. Contribution of top 15 industries to aggregate productivity growth for detailed industries, 1998-2003 


\begin{tabular}{|c|c|c|c|c|c|c|}
\hline \multirow[t]{2}{*}{ Sector } & \multicolumn{6}{|c|}{$\begin{array}{l}\text { Contribution to Total Productivity Growth } \\
\text { [percent per year] }\end{array}$} \\
\hline & 1999 & 2000 & 2001 & 2002 & 2003 & $\begin{array}{c}\text { Average, } \\
1998-2003 \\
\end{array}$ \\
\hline Gross domestic product & 2.33 & 1.56 & 0.50 & 2.92 & 3.10 & 2.08 \\
\hline New economy industries & 1.12 & 0.74 & 0.11 & 0.72 & 1.08 & 0.76 \\
\hline Computer and electronic products & 0.53 & 0.69 & 0.05 & 0.29 & 0.45 & 0.40 \\
\hline Broadcasting and telecommunications & 0.23 & 0.06 & -0.12 & 0.16 & 0.31 & 0.13 \\
\hline Computer systems design and related services & 0.06 & 0.06 & 0.05 & 0.12 & 0.08 & 0.08 \\
\hline Publishing industries (includes software) & 0.20 & -0.07 & 0.07 & 0.05 & 0.13 & 0.07 \\
\hline Information and data processing services & 0.05 & -0.01 & 0.05 & 0.07 & 0.06 & 0.04 \\
\hline Electrical equipment, appliances, and related & 0.05 & 0.01 & 0.00 & 0.03 & 0.05 & 0.03 \\
\hline
\end{tabular}

Table 7. Contribution of New Economy to aggregate productivity growth

\begin{tabular}{|c|c|c|c|c|c|c|}
\hline \multirow[b]{2}{*}{ Sector } & \multicolumn{6}{|c|}{ Average annual growth in variable (logarithmic, percent per year) } \\
\hline & $\begin{array}{c}\text { Labor } \\
\text { productivity }\end{array}$ & Price (a) & Output & $\begin{array}{c}\text { Real } \\
\text { compen- } \\
\text { sation per } \\
\text { worker (a) }\end{array}$ & $\begin{array}{l}\text { Persons } \\
\text { engaged }\end{array}$ & $\begin{array}{c}\text { Share of } \\
\text { compensa } \\
\text { tion }\end{array}$ \\
\hline \multicolumn{7}{|l|}{ Top 5} \\
\hline Computer and electronic products & $25.4 \%$ & $-23.3 \%$ & $19.2 \%$ & $6.9 \%$ & $-6.3 \%$ & $3.0 \%$ \\
\hline Securities, commodity contracts, related & $16.6 \%$ & $-14.6 \%$ & $17.2 \%$ & $4.6 \%$ & $0.6 \%$ & $0.7 \%$ \\
\hline Information and data processing services & $10.6 \%$ & $-0.8 \%$ & $8.7 \%$ & $7.8 \%$ & $-1.9 \%$ & $-3.8 \%$ \\
\hline Apparel and leather and allied products & $10.4 \%$ & $-2.1 \%$ & $-0.7 \%$ & $4.6 \%$ & $-11.1 \%$ & $-5.6 \%$ \\
\hline Air transportation & $10.0 \%$ & $-8.7 \%$ & $8.3 \%$ & $4.2 \%$ & $-1.7 \%$ & $1.0 \%$ \\
\hline \multicolumn{7}{|l|}{ Bottom 5} \\
\hline Petroleum and coal products & $-2.4 \%$ & $7.7 \%$ & $-5.2 \%$ & $11.8 \%$ & $-2.8 \%$ & $4.6 \%$ \\
\hline Other services, except government & $-2.5 \%$ & $3.3 \%$ & $-0.8 \%$ & $3.5 \%$ & $1.7 \%$ & $0.9 \%$ \\
\hline Water transportation & $-2.6 \%$ & $3.4 \%$ & $-1.9 \%$ & $3.8 \%$ & $0.8 \%$ & $1.1 \%$ \\
\hline Educational services & $-2.8 \%$ & $4.2 \%$ & $0.6 \%$ & $4.3 \%$ & $3.3 \%$ & $1.0 \%$ \\
\hline Oil and gas extraction & $-5.3 \%$ & $21.9 \%$ & $-6.6 \%$ & $5.0 \%$ & $-1.3 \%$ & $-13.5 \%$ \\
\hline
\end{tabular}

(a) Price and real compensation are industry price and compensation per worker less growth in price of domestic output.

Table 8. Decomposition of Labor Productivity into Components, Annual Average, 1998-2003 


\begin{tabular}{|c|c|c|c|c|c|}
\hline \multirow[b]{3}{*}{ Equation } & \multirow{3}{*}{$\begin{array}{c}\text { Dependent } \\
\text { variable }\end{array}$} & \multirow{3}{*}{ Period } & \multirow{3}{*}{$\begin{array}{l}\text { Estimation } \\
\text { technique }\end{array}$} & \multicolumn{2}{|c|}{ Independent variables } \\
\hline & & & & $\theta$ & $\begin{array}{c}\text { Lagged } \\
\theta\end{array}$ \\
\hline & & & & \multicolumn{2}{|c|}{ (productivity growth) } \\
\hline 1 & & $1955-2001$ & Pooled LS & $\begin{array}{l}0.05^{* *} \\
0.02\end{array}$ & \\
\hline 2 & & $1955-2001$ & Pooled LS & $\begin{array}{l}0.06 \text { ** } \\
0.02\end{array}$ & $\begin{array}{l}0.04 \\
0.02\end{array}$ \\
\hline 3 & & 1955-2001 & $\begin{array}{c}\text { Pooled } \\
\text { TSLS }\end{array}$ & $\begin{array}{l}0.05 \\
0.03\end{array}$ & \\
\hline 4 & & $1955-2001$ & $\begin{array}{c}\text { Pooled } \\
\text { TSLS }\end{array}$ & $\begin{array}{l}0.05 \\
0.03\end{array}$ & $\begin{array}{l}0.00 \\
0.04\end{array}$ \\
\hline 5 & & $1998-2003$ & Pooled LS & $\begin{array}{l}0.10 \text { * } \\
0.04\end{array}$ & \\
\hline 6 & & 1998-2003 & Pooled LS & $\begin{array}{l}0.13 \text { ** } \\
0.05\end{array}$ & $\begin{array}{l}0.11 \text { * } \\
0.05\end{array}$ \\
\hline 7 & & 1998-2003 & $\begin{array}{c}\text { Pooled } \\
\text { TSLS }\end{array}$ & $\begin{array}{l}0.33 \text { ** } \\
0.10\end{array}$ & \\
\hline 8 & & 1998-2003 & $\begin{array}{c}\text { Pooled } \\
\text { TSLS }\end{array}$ & $\begin{array}{l}0.40 \text { ** } \\
0.11\end{array}$ & $\begin{array}{l}0.17 \\
0.09\end{array}$ \\
\hline
\end{tabular}

Note on statistics: The first number is the coefficient estimate, and the second is the standard error of the coefficient.

* Significant at the 5 percent level.

** Significant at the 1 percent level.

All equations are estimated as first differences of the logarithm with fixed effects for industries and years.

Table 9. Regression Coefficients Showing Effect of Productivity Growth on Employment Growth, For Manufacturing Industries, Various Periods

Estimated equation is (7) from text, $\Delta e_{i, t}=\beta_{i}+\gamma_{t} \Delta a_{i, t}+\varepsilon_{i, t}$, where $\Delta e_{i, t}$ is the annual growth in persons engaged, and $\Delta a_{i, t}$ is the annual growth in output per person. The coefficients in the table are estimates of $\gamma_{l}$. 


\begin{tabular}{|c|c|c|c|c|c|c|}
\hline \multirow[t]{2}{*}{ Sector } & \multicolumn{6}{|c|}{$\begin{array}{l}\text { Productivity Growth per Person Engaged } \\
\text { [percent per year }\rfloor\end{array}$} \\
\hline & 1999 & 2000 & 2001 & 2002 & 2003 & $\begin{array}{l}\text { Average, } \\
\text { 1998-2003 }\end{array}$ \\
\hline Gross domestic product & 2.33 & 1.56 & 0.50 & 2.92 & 3.10 & 2.08 \\
\hline Private industries & 2.58 & 1.76 & 0.91 & 3.40 & 3.28 & 2.39 \\
\hline Farms & 3.38 & 12.10 & -13.94 & 3.96 & 10.89 & 3.28 \\
\hline Forestry, fishing, and related activities & 1.71 & 6.87 & -12.60 & 10.21 & 7.38 & 2.72 \\
\hline Oil and gas extraction & 13.26 & -16.50 & -9.81 & 2.30 & -15.66 & -5.28 \\
\hline Mining, except oil and gas & 12.85 & 5.05 & -4.68 & 0.26 & 7.70 & 4.24 \\
\hline Support activities for mining & 6.81 & 15.98 & -26.35 & 5.39 & 14.46 & 3.26 \\
\hline Utilities & 4.19 & 6.15 & -5.38 & 7.16 & 8.87 & 4.20 \\
\hline Construction & -2.56 & -2.81 & 1.41 & -0.45 & -1.44 & -1.17 \\
\hline Wood products & -1.59 & 5.08 & 1.94 & 0.24 & 4.83 & 2.10 \\
\hline Nonmetallic mineral products & 1.45 & -0.43 & 0.36 & -0.49 & 5.82 & 1.34 \\
\hline Primary metals & 7.34 & -0.20 & -2.67 & 12.68 & 3.26 & 4.08 \\
\hline Fabricated metal products & 0.36 & 5.26 & -5.19 & 4.80 & 7.35 & 2.51 \\
\hline Machinery & -4.89 & 4.88 & -3.05 & 4.43 & 5.39 & 1.35 \\
\hline Computer and electronic products & 28.93 & 37.69 & 2.91 & 22.53 & 35.09 & 25.43 \\
\hline Electrical equipment, appliances, and components & 9.89 & 2.41 & 0.00 & 7.52 & 12.57 & 6.48 \\
\hline Motor vehicles, bodies and trailers, and parts & 0.95 & 3.47 & -5.35 & 18.92 & 11.05 & 5.81 \\
\hline Other transportation equipment & 1.61 & -0.14 & 3.81 & 6.13 & -2.89 & 1.70 \\
\hline Furniture and related products & 1.19 & 2.80 & -8.55 & 3.59 & 0.71 & -0.05 \\
\hline Miscellaneous manufacturing & 3.26 & 9.72 & -2.35 & 5.61 & 5.56 & 4.36 \\
\hline Food and beverage and tobacco products & 0.69 & -0.33 & 0.37 & -0.42 & 2.61 & 0.59 \\
\hline Textile mills and textile product mills & 4.29 & 9.27 & -9.21 & 8.31 & 10.14 & 4.56 \\
\hline Apparel and leather and allied products & 0.95 & 12.30 & -0.31 & 24.72 & 14.47 & 10.43 \\
\hline Paper products & 3.13 & -7.48 & -8.09 & 11.27 & 10.48 & 1.86 \\
\hline Printing and related support activities & 1.56 & 1.94 & -7.93 & 5.82 & 1.89 & 0.66 \\
\hline Petroleum and coal products & -6.25 & -19.47 & -7.54 & 28.28 & -6.91 & -2.38 \\
\hline Chemical products & 4.68 & -0.13 & -0.06 & 10.19 & 8.37 & 4.61 \\
\hline Plastics and rubber products & 3.84 & 2.40 & -1.52 & 8.40 & 7.70 & 4.17 \\
\hline Wholesale trade & 3.46 & -1.69 & 11.35 & 3.80 & -2.35 & 2.91 \\
\hline Retail trade & 2.81 & 2.09 & 3.09 & 6.48 & 5.78 & 4.05 \\
\hline Air transportation & 4.50 & 4.72 & -0.29 & 16.06 & 24.93 & 9.99 \\
\hline Rail transportation & 1.57 & 7.81 & 0.60 & 1.84 & 3.32 & 3.03 \\
\hline Water transportation & -9.54 & 8.82 & -3.53 & -5.73 & -3.18 & -2.63 \\
\hline Truck transportation & -1.91 & -0.90 & -5.85 & 1.59 & 2.06 & -1.00 \\
\hline Transit and ground passenger transportation & 0.41 & -1.14 & -7.71 & 0.95 & -1.15 & -1.73 \\
\hline Pipeline transportation & 8.49 & 14.18 & -4.45 & 3.03 & 0.49 & 4.35 \\
\hline Other transportation and support activities & 2.89 & 2.64 & -5.77 & 6.14 & 2.81 & 1.74 \\
\hline Warehousing and storage & 3.89 & 4.41 & -5.03 & 10.84 & 8.94 & 4.61 \\
\hline Publishing industries (includes software) & 16.75 & -5.68 & 5.89 & 4.03 & 11.46 & 6.49 \\
\hline Motion picture and sound recording industries & 6.47 & 0.80 & 0.68 & -1.25 & 5.64 & 2.47 \\
\hline Broadcasting and telecommunications & 8.56 & 2.18 & -4.16 & 6.05 & 12.05 & 4.94 \\
\hline Information and data processing services & 12.79 & -2.24 & 13.06 & 16.11 & 13.21 & 10.58 \\
\hline Federal Reserve banks and related & 5.76 & -1.19 & 3.70 & 5.40 & 1.83 & 3.10 \\
\hline Securities, commodity contracts, and investments & 16.42 & 33.28 & 10.65 & 4.87 & 18.00 & 16.64 \\
\hline Insurance carriers and related activities & -2.24 & 6.93 & -6.35 & -2.36 & 1.61 & -0.48 \\
\hline Funds, trusts, and other financial vehicles & -23.11 & -28.95 & 30.63 & -6.09 & 21.24 & -1.26 \\
\hline Real estate & 2.62 & 2.39 & -0.07 & -0.57 & -3.72 & 0.13 \\
\hline Rental and leasing services and related & 1.83 & -1.32 & -1.27 & 1.67 & 1.36 & 0.45 \\
\hline Legal services & -0.37 & 1.41 & 2.14 & -1.71 & -0.10 & 0.27 \\
\hline Computer systems design and related services & 5.78 & 5.07 & 4.33 & 9.83 & 6.79 & 6.36 \\
\hline Rental and leasing services and related & 2.73 & 4.31 & 1.78 & 4.75 & 2.14 & 3.14 \\
\hline Management of companies and enterprises & -0.78 & -2.80 & -1.40 & 1.37 & 3.25 & -0.07 \\
\hline Administrative and support services & -0.59 & -11.42 & 0.86 & 6.74 & 5.27 & 0.17 \\
\hline Waste management and remediation services & 7.95 & 1.44 & -6.68 & 3.23 & 7.53 & 2.69 \\
\hline Educational services & -1.38 & -0.94 & -4.36 & -3.64 & -3.50 & -2.76 \\
\hline Health care and social assistance & -0.27 & 0.62 & -0.51 & 1.26 & 0.96 & 0.41 \\
\hline Arts, entertainment, and recreation & 1.01 & -3.46 & -1.39 & 1.79 & -0.30 & -0.47 \\
\hline Accommodation & 0.11 & 1.35 & -7.48 & 6.22 & 2.07 & 0.45 \\
\hline Food services and drinking places & 0.51 & 1.13 & 4.90 & -0.54 & 0.70 & 1.34 \\
\hline Other services, except government & -3.23 & -1.68 & -3.19 & -4.17 & -0.28 & -2.51 \\
\hline General government & 0.55 & -0.50 & 2.72 & 0.81 & 0.93 & 0.90 \\
\hline Government enterprises & -0.83 & 6.73 & -10.72 & 4.68 & 2.97 & 0.57 \\
\hline General government & 0.44 & 0.36 & -0.41 & -0.53 & -0.16 & -0.06 \\
\hline Government enterprises & 3.43 & 2.84 & -7.73 & -7.61 & 3.44 & -1.13 \\
\hline
\end{tabular}

Table A-1. Productivity Growth by Detailed Industry 


\begin{tabular}{|c|c|c|c|c|c|c|}
\hline \multirow[t]{2}{*}{ Sector } & \multicolumn{6}{|c|}{$\begin{array}{l}\text { Contribution to Total Productivity Growth } \\
\text { [percent per year] }\end{array}$} \\
\hline & 1999 & 2000 & 2001 & 2002 & 2003 & $\begin{array}{l}\text { Average, } \\
\text { 1998-2003 }\end{array}$ \\
\hline Gross domestic product & 2.33 & 1.56 & 0.50 & 2.92 & 3.10 & 2.08 \\
\hline Private industries & 2.58 & 1.76 & 0.91 & 3.40 & 3.28 & 2.09 \\
\hline Farms & 0.03 & 0.09 & -0.10 & 0.03 & 0.08 & 0.02 \\
\hline Forestry, fishing, and related activities & 0.00 & 0.02 & -0.03 & 0.03 & 0.02 & 0.01 \\
\hline Oil and gas extraction & 0.06 & -0.11 & -0.08 & 0.01 & -0.10 & -0.04 \\
\hline Mining, except oil and gas & 0.04 & 0.01 & -0.01 & 0.00 & 0.02 & 0.01 \\
\hline Support activities for mining & 0.01 & 0.02 & -0.04 & 0.01 & 0.02 & 0.00 \\
\hline Utilities & 0.09 & 0.12 & -0.11 & 0.14 & 0.18 & 0.08 \\
\hline Construction & -0.11 & -0.12 & 0.06 & -0.02 & -0.07 & -0.05 \\
\hline Wood products & -0.01 & 0.02 & 0.01 & 0.00 & 0.01 & 0.01 \\
\hline Nonmetallic mineral products & 0.01 & 0.00 & 0.00 & 0.00 & 0.02 & 0.01 \\
\hline Primary metals & 0.04 & 0.00 & -0.01 & 0.05 & 0.01 & 0.02 \\
\hline Fabricated metal products & 0.00 & 0.07 & -0.06 & 0.05 & 0.08 & 0.03 \\
\hline Machinery & -0.06 & 0.05 & -0.03 & 0.04 & 0.05 & 0.01 \\
\hline Computer and electronic products & 0.53 & 0.69 & 0.05 & 0.29 & 0.45 & 0.40 \\
\hline Electrical equipment, appliances, and components & 0.05 & 0.01 & 0.00 & 0.03 & 0.05 & 0.03 \\
\hline Motor vehicles, bodies and trailers, and parts & 0.01 & 0.04 & -0.06 & 0.20 & 0.12 & 0.06 \\
\hline Other transportation equipment & 0.01 & 0.00 & 0.03 & 0.04 & -0.02 & 0.01 \\
\hline Furniture and related products & 0.00 & 0.01 & -0.03 & 0.01 & 0.00 & 0.00 \\
\hline Miscellaneous manufacturing & 0.02 & 0.06 & -0.01 & 0.03 & 0.03 & 0.02 \\
\hline Food and beverage and tobacco products & 0.01 & -0.01 & 0.01 & -0.01 & 0.04 & 0.01 \\
\hline Textile mills and textile product mills & 0.01 & 0.03 & -0.02 & 0.02 & 0.02 & 0.01 \\
\hline Apparel and leather and allied products & 0.00 & 0.03 & 0.00 & 0.06 & 0.03 & 0.02 \\
\hline Paper products & 0.02 & -0.04 & -0.04 & 0.05 & 0.05 & 0.01 \\
\hline Printing and related support activities & 0.01 & 0.01 & -0.04 & 0.03 & 0.01 & 0.00 \\
\hline Petroleum and coal products & -0.02 & -0.05 & -0.02 & 0.08 & -0.02 & -0.01 \\
\hline Chemical products & 0.08 & 0.00 & 0.00 & 0.16 & 0.14 & 0.07 \\
\hline Plastics and rubber products & 0.03 & 0.02 & -0.01 & 0.05 & 0.05 & 0.03 \\
\hline Wholesale trade & 0.21 & -0.10 & 0.68 & 0.23 & -0.14 & 0.18 \\
\hline Retail trade & 0.19 & 0.14 & 0.21 & 0.45 & 0.41 & 0.28 \\
\hline Air transportation & 0.03 & 0.03 & 0.00 & 0.08 & 0.12 & 0.05 \\
\hline Rail transportation & 0.00 & 0.02 & 0.00 & 0.00 & 0.01 & 0.01 \\
\hline Water transportation & -0.01 & 0.01 & 0.00 & 0.00 & 0.00 & 0.00 \\
\hline Truck transportation & -0.02 & -0.01 & -0.05 & 0.01 & 0.02 & -0.01 \\
\hline Transit and ground passenger transportation & 0.00 & 0.00 & -0.01 & 0.00 & 0.00 & 0.00 \\
\hline Pipeline transportation & 0.01 & 0.01 & 0.00 & 0.00 & 0.00 & 0.00 \\
\hline Other transportation and support activities & 0.02 & 0.02 & -0.04 & 0.04 & 0.02 & 0.01 \\
\hline Warehousing and storage & 0.01 & 0.01 & -0.01 & 0.03 & 0.03 & 0.01 \\
\hline Publishing industries (includes software) & 0.20 & -0.07 & 0.07 & 0.05 & 0.13 & 0.07 \\
\hline Motion picture and sound recording industries & 0.02 & 0.00 & 0.00 & 0.00 & 0.02 & 0.01 \\
\hline Broadcasting and telecommunications & 0.23 & 0.06 & -0.12 & 0.16 & 0.31 & 0.13 \\
\hline Information and data processing services & 0.05 & -0.01 & 0.05 & 0.07 & 0.06 & 0.04 \\
\hline Federal Reserve banks and related & 0.19 & -0.04 & 0.13 & 0.20 & 0.07 & 0.11 \\
\hline Securities, commodity contracts, and investments & 0.25 & 0.54 & 0.18 & 0.08 & 0.27 & 0.26 \\
\hline Insurance carriers and related activities & -0.05 & 0.17 & -0.15 & -0.05 & 0.04 & -0.01 \\
\hline Funds, trusts, and other financial vehicles & -0.03 & -0.05 & 0.05 & -0.01 & 0.04 & 0.00 \\
\hline Real estate & 0.29 & 0.26 & -0.01 & -0.07 & -0.43 & 0.01 \\
\hline Rental and leasing services and related & 0.02 & -0.01 & -0.01 & 0.02 & 0.01 & 0.00 \\
\hline Legal services & -0.01 & 0.02 & 0.03 & -0.02 & 0.00 & 0.00 \\
\hline Computer systems design and related services & 0.06 & 0.06 & 0.05 & 0.12 & 0.08 & 0.08 \\
\hline Rental and leasing services and related & 0.11 & 0.18 & 0.07 & 0.20 & 0.09 & 0.13 \\
\hline Management of companies and enterprises & -0.01 & -0.05 & -0.03 & 0.02 & 0.06 & 0.00 \\
\hline Administrative and support services & -0.02 & -0.31 & 0.02 & 0.18 & 0.14 & 0.00 \\
\hline Waste management and remediation services & 0.02 & 0.00 & -0.02 & 0.01 & 0.02 & 0.01 \\
\hline Educational services & -0.01 & -0.01 & -0.04 & -0.03 & -0.03 & -0.02 \\
\hline Health care and social assistance & -0.02 & 0.04 & -0.03 & 0.08 & 0.07 & 0.03 \\
\hline Arts, entertainment, and recreation & 0.01 & -0.03 & -0.01 & 0.02 & 0.00 & 0.00 \\
\hline Accommodation & 0.00 & 0.01 & -0.07 & 0.05 & 0.02 & 0.00 \\
\hline Food services and drinking places & 0.01 & 0.02 & 0.09 & -0.01 & 0.01 & 0.02 \\
\hline Other services, except government & -0.08 & -0.04 & -0.08 & -0.10 & -0.01 & -0.06 \\
\hline General government & 0.02 & -0.02 & 0.09 & 0.03 & 0.03 & 0.03 \\
\hline Government enterprises & -0.01 & 0.04 & -0.07 & 0.03 & 0.02 & 0.00 \\
\hline General government & 0.03 & 0.03 & -0.03 & -0.04 & -0.01 & -0.01 \\
\hline Government enterprises & 0.03 & 0.02 & -0.05 & -0.05 & 0.02 & -0.01 \\
\hline
\end{tabular}

Table A-2. Contribution to Aggregate Productivity Growth by Detailed Industry 


\begin{tabular}{|c|c|c|c|}
\hline Sector & $\begin{array}{c}\text { Hours of Self } \\
\text { Employed as } \\
\text { Percent of Total } \\
\text { Hours, 2000-2003 }\end{array}$ & $\begin{array}{l}\text { Average Change } \\
\text { in Hours of Self } \\
\text { Employed, 1987- } \\
2000\end{array}$ & $\begin{array}{l}\text { Average Change } \\
\text { in Hours of Self } \\
\text { Employed, 2000- } \\
2003\end{array}$ \\
\hline Domestic industries & $4.4 \%$ & $-0.06 \%$ & $0.05 \%$ \\
\hline Private industries & $0.5 \%$ & & $0.00 \%$ \\
\hline Agriculture, forestry, fishing, and hunting & $35.8 \%$ & $-0.97 \%$ & $-1.03 \%$ \\
\hline Farms & $53.4 \%$ & $-0.65 \%$ & $0.33 \%$ \\
\hline Forestry, fishing, and related activities & $9.2 \%$ & $-0.58 \%$ & $-1.17 \%$ \\
\hline Mining & $1.1 \%$ & $-0.03 \%$ & $-0.01 \%$ \\
\hline Utilities & $0.0 \%$ & $-0.01 \%$ & $0.00 \%$ \\
\hline Construction & $12.1 \%$ & $-0.18 \%$ & $0.08 \%$ \\
\hline Manufacturing & $1.1 \%$ & $0.00 \%$ & $0.07 \%$ \\
\hline Durable goods & $1.1 \%$ & $0.00 \%$ & $0.06 \%$ \\
\hline Nondurable goods & $1.1 \%$ & $0.00 \%$ & $0.08 \%$ \\
\hline Wholesale trade & $2.1 \%$ & $-0.05 \%$ & $0.07 \%$ \\
\hline Retail trade & $4.4 \%$ & $-0.13 \%$ & $0.03 \%$ \\
\hline Transportation and warehousing & $4.8 \%$ & & $0.16 \%$ \\
\hline Information & $2.2 \%$ & & $0.21 \%$ \\
\hline Finance and insurance, real estate, other & $5.2 \%$ & $0.01 \%$ & $0.00 \%$ \\
\hline Services & & $-0.18 \%$ & \\
\hline Professional and business services & $6.6 \%$ & & $0.14 \%$ \\
\hline Educational services, health care, other & $4.2 \%$ & & $-0.10 \%$ \\
\hline Arts, entertainment, recreation, other & $3.8 \%$ & & $0.02 \%$ \\
\hline Other services, except government & $10.3 \%$ & & $0.17 \%$ \\
\hline Government & $0.0 \%$ & & $0.00 \%$ \\
\hline General government & $0.0 \%$ & & $0.00 \%$ \\
\hline Government enterprises & $0.0 \%$ & & $0.00 \%$ \\
\hline
\end{tabular}

Notes: Data from BEA web page. Data for 1987-2000 use SIC classification, while 2000-2003 use NAICS classification. The industry definitions are consistent within each column but differ slightly between the two sub-periods. For each estimate, I assume that self-employed workers work 1000 hours per year.

Table A-3. Change in share of hours of self-employed workers 